\title{
Comparative Trophic Morphology in Eight Species of Damselfishes (Pomacentridae)
}

\author{
Bruno Frédérich, ${ }^{*}$ Arnaud Pilet, Eric Parmentier, and Pierre Vandewalle
}

Laboratoire de Morphologie fonctionnelle et évolutive, Institut de Chimie (B6c), Université de Liège, B-4000 Liège, Belgium

\begin{abstract}
Damselfishes show significant biodiversity in the coral reefs. To better understand such diversity, an ecomorphological approach was investigated in the trophic morphology of eight species of Pomacentridae (Chromis acares, C. margaritifer, Dascyllus aruanus, D. flavicaudus, Pomacentrus pavo, Plectroglyphidodon johnstonianus, Pl. lacrymatus and Stegastes nigricans) belonging to different trophic guilds (zooplankton, algal, coral polyp feeders and omnivores). Geometric morphometrics were used to quantify size and shape variations in four skeletal units: (1) neurocranium, (2) suspensorium and opercle, (3) mandible and (4) premaxilla. This method allowed us to reveal shape and size differences correlated to functional diversity both within and between trophic guilds. Among zooplanktivores, C. margaritifer, $D$. aruanus and $D$. flavicaudus have a high and long supraoccipital crest, short mandibles forming a small mouth and high suspensoria and opercles. These three species can be considered to be suction feeders. In the same guild, $C$. acares shows opposite characteristics (long and thin mandibles, lengthened neurocranium and suspensorium) and can be considered as a ram feeder. Among herbivores and corallivores, the two species of Plectroglyphidodon and S. nigricans can be considered as grazers. Differences in skeletal shape are mainly related to improving the robustness of some skeletal parts (broad hyomandibular, short and high mandibles). The shapes of $P$. pavo, which feeds largely on algae, strongly differ from that of the other three grazers exhibiting similar morphological characteristics to $C$. acares (e.g., long and shallow suspensorium, lengthened neurocranium). This highlights likely differences concerning cutting or scraping method. Finally, no strong correlations exist between size and shapes in the eight studied species. Size difference among species having a very similar shape could be viewed as a factor optimizing resource partitioning. J. Morphol. 269:175-188, 2008. (c) 2007 Wiley-Liss, Inc.
\end{abstract}

KEY WORDS: Pomacentridae; geometric morphometrics; feeding apparatus; ecomorphology

The ecomorphological approach examines the association between the morphology of an organism and its lifestyle (Norton et al., 1995; Wainwright, 1996). It discusses the optimization of a form-function complex in a given ecological niche placing, for example, in parallel the diet of an organism and its biomechanics of prey capture
(Barel, 1983; Wainwright, 1988; Kotrschal, 1989; Sanderson, 1990; Turingan, 1994). Skull morphology is subjected to various constraints dealing with the strategy of feeding and the type of ingested food (Liem, 1979, 1993; Wainwright and Richard, 1995). Morphological adaptations related to diet are numerous. These concern the buccopharyngeal cavity and in particular, the oral jaws and their teeth, which contribute to seizure of food and secondly, the pharyngeal jaws and their teeth, which are involved in the preparation of food before ingestion (Wainwright and Bellwood, 2002). Consequently, it is possible to identify various trophic groups in the same family of fishes by structural and form differences in these structures (Barel, 1983). Accordingly, many studies have explored the relationship between the shape of the neurocranium, buccopharyngeal cavity, jaws and teeth on the one hand and diet on the other in different diverse fish families like the Cichlidae (Liem and Osse, 1975; Liem, 1979; Kassam et al., 2004), the Labridae (Wainwright, 1988; Clifton and Motta, 1998; Wainwright et al., 2004), the Centrarchidae (Wainwright and Richard, 1995) and the Chaetodontidae (Motta, 1988).

The Pomacentridae, or damselfishes, includes more than 330 species living mainly in a coral reef environment (Allen, 1991; Nelson, 2006). In terms of species number, this family represents the third group in the coral ecosystem after the Gobiidae ( $>1,500$ species) and the Labridae ( $>450$ species) (Wainwright and Bellwood, 2002). This diversity seems to contrast with a rather uniform external morphology (Allen, 1991; Wainwright and Bellwood, 2002). However, damselfishes are a group showing great ecological and food diversity (Emery,

Contract grant sponsor: Fonds National de la Recherche Scientifique, Belgium.

\footnotetext{
*Correspondence to: Bruno Frédérich, Laboratoire de Morphologie fonctionnelle et évolutive, Institut de Chimie (B6c), Université de Liège, B-4000 Liège, Belgium. E-mail: bruno.frederich@ulg.ac.be
}

Published online 12 October 2007 in

Wiley InterScience (www.interscience.wiley.com)

DOI: $10.1002 /$ jmor. 10586 
1973; Meekan et al., 1995; Ormond et al., 1996). Studies of stomach contents reveal that damselfishes include planctivores, herbivores, coral predators or omnivores (Kuo and Shao, 1991). The first ecomorphological studies in this family (Emery, 1973; Gluckmann and Vandewalle, 1998) suggested that a detailed study of cephalic morphology could show different trophic groups and that this could explain a part of the diversity of Pomacentridae.

The first aim of the present study is to characterize size and shape of different cephalic structures directly implied in feeding in eight species of Pomacentridae. The second aim is to determine, on the basis of shape variations in bony elements, whether these species show different feeding performance and/or use different strategies of prey capture. Such differences could reveal diverse functional adaptations explaining the diversity in the Pomacentridae.

\section{MATERIALS AND METHODS Specimens}

The eight species: Chromis acares Randall and Swerdloff, 1973; Chromis margaritifer Fowler, 1946; Dascyllus aruanus Linnaeus, 1758; Dascyllus flavicaudus Randall and Allen, 1977; Pomacentrus pavo Bloch, 1787; Plectroglyphidodon johnstonianus Fowler and Ball, 1934; Plectroglyphidodon lacrymatus Quoy and Gaimard, 1825; and Stegastes nigricans Lacepède 1802; were selected on the basis of two criteria: their diet (Table 1) (Allen, 1991; Kuo and Shao, 1991) and their phylogenetic position (Quenouille et al., 2004). All species were collected in Moorea (Society Islands, French Polynesia) in July and August 1998 except D. aruanus, which was sampled in Toliara (Madagascar) in June 2002 (Table 1). All specimens were collected after being anaesthetized by rotenone or by a solution of quinaldine. Fishes were preserved in neutralized and buffered $10 \%$ formalin for 10 days, then transferred to $70 \%$ alcohol. All chosen individuals were adult or sub-adult, being a size sufficiently close to their maximum standard length (SL) (Allen, 1991) in order to avoid any problems relating to possible differences in diet in relation to their ontogeny (Table 1) (Clements and Choat, 1993; McCormick, 1998; Monteiro et al., 2005). All specimens were cleared and stained with alizarin red $\mathrm{S}$ (Taylor and Van Dyke, 1985) in order to display the osseous skeleton.

\section{Geometric Morphometrics and Statistical Analyses}

Size and shape variability of (1) the neurocranium, (2) the suspensorium and the opercle, (3) the mandible and (4) the premaxilla were studied using landmark-based geometric morphometric methods (Bookstein, 1991; Rohlf and Marcus, 1993; Marcus et al., 1996). The study of individual skeletal units was chosen because (1) they enable us to reveal patterns of morphological variation that are obscured if external morphology alone or articulated skeletons is considered and (2) they prove to be very informative in studies of trophic adaptations in other fishes like Cichlidae (e.g., Barel, 1983).

Each skeletal unit (in lateral view) was analyzed separately. In each species, 17 homologous landmarks were defined on the neurocranium, 16 on the "suspensorium and opercle" unit, 12 on the mandible and 6 on the premaxilla (Fig. 1, Table 2). These were chosen according to their accuracy of digitization and homologization, as well as in order to represent the unit and its parts as accurately as possible. The preopercle was not considered in the "suspensorium and opercle" unit. Its form does not allow the choice of homologous landmarks between species. Landmarks were localized on all specimens of each species using a Leica M10 binocular microscope coupled to a camera lucida. Then the coordinates of the landmarks were digitized using TpsDig (version 1.39). Landmark configurations of each of the four structures of all specimens $(n=59)$ were superimposed using a "Generalized Procrustes Analysis" (Rohlf and Slice, 1990) to remove non-shape variation (scale, orientation, translation). This Procrustes procedure allows size and shape to be considered as two independent components.

The size, expressed as centroid size (Bookstein, 1991), was compared for each bony element across species with a one-way analysis of variance (ANOVA).

Relative warp (RW) analysis of the shape variables (Partial warp scores [PWs] including both uniform and non-uniform components) was used (Bookstein, 1991; Rohlf, 1993), as exploratory methods, for ordinations and to investigate trends of shape variations among species. Deformation grids using thinplate spline (TPS) algorithm were used to visualise the patterns of shape variations (Thompson, 1917; Bookstein, 1991; Rohlf, 1993, 1996). The average (consensus) configuration of landmarks for each species was computed using Morpheus et al. (beta version) and was included in the RW analyses. These help to show the deviations of each specimen from its species mean in the shape space.

Multivariate analysis of variance (MANOVA) and canonical variate analysis (CVA) were also performed on all shape variables (PWs) for comparing shape of each skeletal element among species. When the MANOVA revealed significant differences among species, pairwise multiple comparisons using generalized Mahalanobis distance were performed to determine which species differed from one another. To allow interpretation of shape variation along the canonical variates axes $(\mathrm{CVs})$, PWs (uniform

TABLE 1. Species included in this study

\begin{tabular}{|c|c|c|c|c|}
\hline Species & Diet & $\mathrm{SL}^{\max }$ & $n$ & $\mathrm{SL}^{\mathrm{mm}}$ \\
\hline Chromis acares & Zooplankton (Allen, 1991) & 40 & 8 & $33 \leq \mathrm{SL} \leq 37$ \\
\hline Chromis margaritifer & Zooplankton (Kuo and Shao, 1991) & 80 & 9 & $53 \leq \mathrm{SL} \leq 61$ \\
\hline Dascyllus aruanus & $\begin{array}{l}\text { Omnivorous feeding largely on zooplankton } \\
\text { (Kuo and Shao, 1991) }\end{array}$ & 65 & 7 & $33 \leq \mathrm{SL} \leq 43$ \\
\hline Dascyllus flavicaudus & $\begin{array}{l}\text { Omnivorous feeding largely on zooplankton } \\
\text { (Allen, 1991) }\end{array}$ & 90 & 6 & $52 \leq \mathrm{SL} \leq 69$ \\
\hline Plectroglyphidodon johnstonianus & Coral polyp feeder (Kuo and Shao, 1991) & 70 & 10 & $65 \leq \mathrm{SL} \leq 74$ \\
\hline Plectroglyphidodon lacrymatus & Herbivorous (Kuo and Shao, 1991) & 80 & 4 & $55 \leq \mathrm{SL} \leq 67$ \\
\hline Pomacentrus pavo & Omnivorous feeding largely on algae (Allen, 1991) & 85 & 10 & $42 \leq \mathrm{SL} \leq 58$ \\
\hline Stegastes nigricans & Herbivorous (Kuo and Shao, 1991) & 140 & 5 & $94 \leq \mathrm{SL} \leq 127$ \\
\hline
\end{tabular}

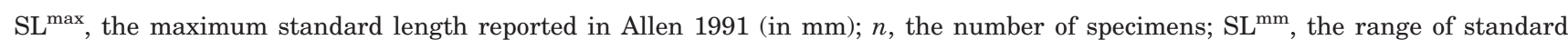
length of studied specimens (in $\mathrm{mm}$ ). 

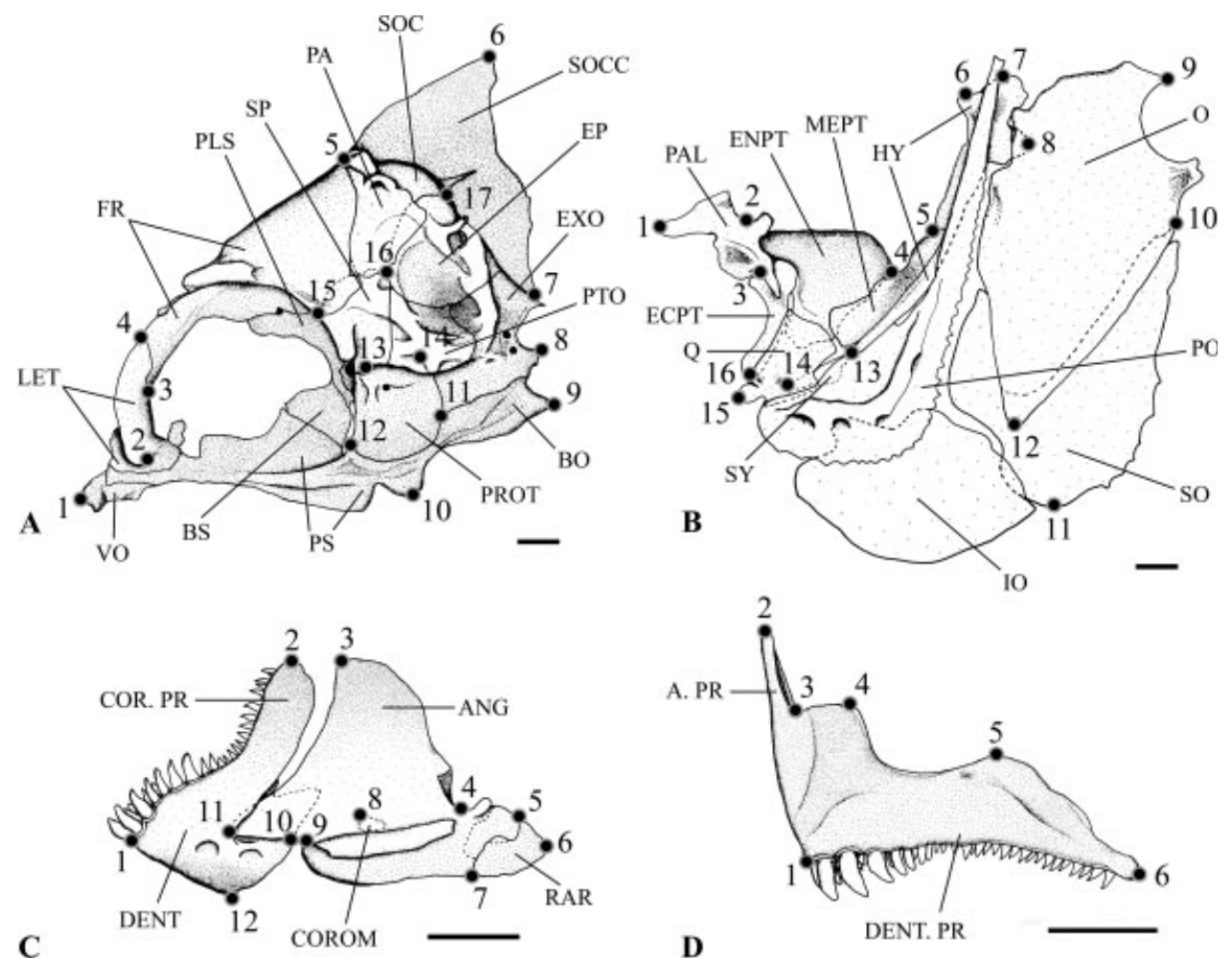

Fig. 1. Dascyllus aruanus. Localization of the different landmarks (LM) on, (A) the neurocranium; (B) the suspensorium and the opercle; $(\mathbf{C})$ the mandible and $(\mathbf{D})$ the premaxilla. Scale bars $=1 \mathrm{~mm}$. ANG, articulo-angular; APR, ascending process of the premaxilla; BO, basioccipital; BS, basisphenoid; COR.PR, coronoid process; COROM, coronomeckelien; DENT, dentary; DENT.PR, dentigerous process; ECPT, ectopterygoid; ENPT, entopterygoid; EP, epiotic; EXO, exoccipital; FR, frontal; HM, hyomandibular; IO, interoperculum; LET, lateral ethmoid; MEPT, metapterygoid; O, operculum; PA, parietal; PAL, palatine; PLS, pleurosphenoid; PO, preoperculum; PROT, prootic; PS, parasphenoid; PTO, pterotic; Q, quadrate; RAR, retroarticular; SO, suboperculum; SOC, supraoccipital; SOCC, supraoccipital crest; SP, sphenotic; SY, symplectic; VO, vomer.

and non-uniform components) were regressed against the $\mathrm{CV}$ axes in the program TpsRegr (version 1.28), and TPS deformations grids representing extreme positive and negative deviations along CV1 and CV2 axis were examined.

The patterns of shape variation related to bony element size were compared across species with a multivariate regression of the shape variables onto CS (TpsRegr v1.28) (Monteiro, 1999).

In addition to these analyses, a cluster analysis was also performed for each skeletal unit to illustrate phenetic relationships between species. This procedure was applied to the matrix of Procrustes distances (Rohlf, 1999) among the mean shapes of each species (Cardini, 2003). Procrustes distances were chosen because they express the morphological relationships among species computed directly in the shape space (Rohlf, 1999). Phenograms based on the Procrustes distances between all pairs of consensuses were calculated using a UPGMA algorithm.

ANOVA, MANOVA, CVA and cluster analyses were computed with STATISTICA, version 7.1 (Statsoft 2005). Morphometric softwares used (TpsDig, v1.39; TpsRelw, v1.42; TpsSmall, v1.20; TpsRegr, v1.28; Morpheus et al.) are freely available at: http:// life.bio.sunysb.edu/morph/.

\section{RESULTS}

\section{Size}

There were significant differences between the centroid size (CS) of each species for all bone elements (one-way ANOVA, $P<0.0001$ ). As suggested by Figure 2, a positive correlation exists between the SL and the CS of each structure. For example, Stegastes nigricans and Chromis acares show respectively the longest and the shortest SL, and consequently they have the highest and the smallest CS for each element. This observation was strengthened by results of linear regressions between SL and CS $\left(R^{2}>0.7, P<0.0001\right.$ in each structure). However Pomacentrus pavo, which is a larger species than $C$. acares according to its SL, presents a neurocranium and a unit "suspensorium and opercle" with a CS very close to the latter.

\section{Shape}

Main shape variations across species can be examined by a distribution of specimens in a shape space defined by the axes RW1 and RW2 (Figs. 3, 4). Intraspecific shape variability exists in every skeletal structure. The highest and the lowest deviations respectively concern the shape of the neurocranium and the mandible.

For the neurocranium, the first two RWs accounted for $58.6 \%$ of the shape variation (RW1 $=45.8 \%$ and RW2 $=12.8 \%$ ) (Fig. 3). Three groups are distinguished along the RW1 axis, a first 
TABLE 2. Descriptions of landmarks

\begin{tabular}{|c|c|c|}
\hline Element & Landmarks & Descriptions \\
\hline \multirow[t]{17}{*}{ Neurocranium (a) } & 1 & Former end of the vomer \\
\hline & 2 & Zone of articulation of the palatine on the lateral ethmoid \\
\hline & 3 & Antero-dorsal end of the frontal \\
\hline & 4 & Antero-ventral end of the frontal \\
\hline & 5 & Anterior-most point of the supraoccipital crest \\
\hline & 6 & Top of the supraoccipital crest \\
\hline & 7 & Postero-dorsal end of the exoccipital \\
\hline & 8 & Postero-ventral end of the exoccipital \\
\hline & 9 & Posterior end of the basioccipital \\
\hline & 10 & Articulation of the upper pharyngeal jaws \\
\hline & 11 & Junction between basioccipital, exoccipital and prootic \\
\hline & 12 & Antero-ventral end of the prootic \\
\hline & 13 & Anterior articulation fossa of the hyomandibular on the sphenotic \\
\hline & 14 & Posterior articulation fossa of the hyomandibular on the pterotic \\
\hline & 15 & Postero-ventral end of the frontal \\
\hline & 16 & Junction between sphenotic, pterotic, parietal, and epiotic \\
\hline & 17 & Dorsal junction between epiotic and supraoccipital crest \\
\hline \multirow[t]{16}{*}{ Suspensorium and opercle (b) } & 1 & Anterior-most point of the maxillar process of the palatin \\
\hline & 2 & Articulation of the palatin on lateral ethmoid \\
\hline & 3 & Dorsal contact between ectopterygoid and palatine \\
\hline & 4 & Dorsal junction between metapterygoid and entopterygoid \\
\hline & 5 & Dorsal limit between the metapterygoid and the hyomandibular \\
\hline & 6 & Anterior articulation condyle of the hyomandibular on the sphenotic \\
\hline & 7 & Posterior articulation condyle of the hyomandibular on the pterotic \\
\hline & 8 & Opercular condyle of the hyomandibular \\
\hline & 9 & Postero-dorsal end of the opercle \\
\hline & 10 & Posterior intersection between the opercle and the subopercle \\
\hline & 11 & Ventral end of the subopercle \\
\hline & 12 & Ventral end of the opercle \\
\hline & 13 & Antero-ventral end of the hyomandibular \\
\hline & 14 & Antero-ventral end of the symplectic \\
\hline & 15 & Articulation process of the quadrate \\
\hline & 16 & Ventral contact between ectopterygoid and quadrate \\
\hline \multirow[t]{12}{*}{ Lower jaw (c) } & 1 & Rostral tip of the dentary \\
\hline & 2 & Dorsal tip of the coronoid process of the dentary \\
\hline & 3 & Dorsal tip of the articular process \\
\hline & 4 & Articulation fossa of articulo-angular with the quadrate \\
\hline & 5 & Dorsal tip of the retroarticular \\
\hline & 6 & Posterior end of the retroarticular \\
\hline & 7 & Anterior-most point of the retroarticular \\
\hline & 8 & Dorsal tip of the coronomeckelien \\
\hline & 9 & Ventral start of anterior process of the articulo-angular \\
\hline & 10 & Posterior end of the dentary \\
\hline & 11 & Anterior-most point of the articulo-angular \\
\hline & 12 & Ventral-most point of the dentary \\
\hline \multirow[t]{6}{*}{ Premaxilla (d) } & 1 & Anterior-most point of the dentigerous process \\
\hline & 2 & Tip of the ascending process \\
\hline & 3 & Ventral-most point of the interprocess edge \\
\hline & 4 & Dorsal point of the area which receives the maxillary process \\
\hline & 5 & Crest of the dentigerous process \\
\hline & 6 & Posterior end of the dentigerous process \\
\hline
\end{tabular}

including only Dascyllus flavicaudus, a second grouping Chromis margaritifer, $D$. aruanus, the two species of Plectroglyphidodon and Stegastes nigricans, and a third including $C$. acares and Pomacentrus pavo. Main shape differences between these groups are due to a neurocranium that is proportionally longer in $C$. acares and $P$. pavo. More specifically, these differences are mainly explained by a less high supraoccipital crest (LM 5, 6, and 7) and a ventral part of the neurocranium, including the parasphenoid and the vomer, longer than that of the other species (LM 1,
10). In contrast, D. flavicaudus has the highest neurocranium and thus its neurocranium is proportionally the shortest. This results from a high frontal region (LM 4, 5, 15), a high supraoccipital crest and a short parasphenoid. RW2 axis permits isolation of $S$. nigricans and D. aruanus in the second group while $C$. margaritifer, $P l$. lacrymatus and $P l$. johnstonianus are intermediate and share a relatively similar neurocranium. Stegastes nigricans is directly opposite to $D$. aruanus due to a forehead that is aligned perfectly with the front of the supraoccipital crest (LM 4, 5 and 6 are 

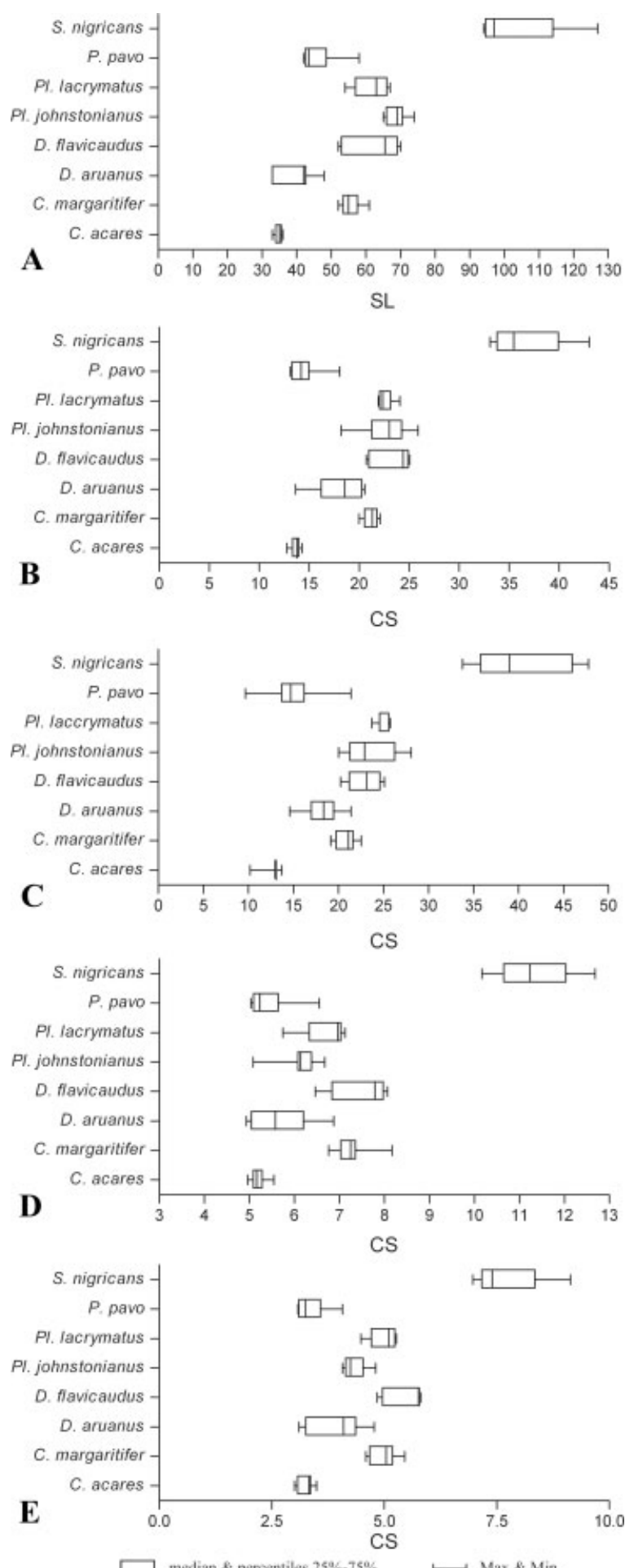

Fig. 2. Box plots of (A) the standard length, SL and (B-E) the centroid size, CS of each skeletal unit for all studied species; (B) the neurocranium, (C) the "suspensorium and opercle" unit, (D) the mandible and (E) the premaxilla.

aligned), a broad prootic (LM 10, 11), a high ethmoidal region (LM 1,4) and a vomer that is ventrally directed (LM 1,2). To a lesser extent, these characters differentiate $P$. pavo from $C$. acares.
The shape variation in the suspensoria and opercles explained by RW1 and RW2 is $53 \%$ of the total variation (Fig. 3). Chromis acares and Pomacentrus pavo have the highest RW1 score and Dascyllus flavicaudus has the lowest. The two Dascyllus species have the highest and narrowest "suspensorium and opercle" unit. In these two species, the opercle is the narrowest (LM 9 and 10) and their maxillary process of the palatine is stocky and bent (LM 1 and 2). The suspensorium of $C$. acares and $P$. pavo is less high and longer. The difference in height seems to be the most important at the level of the anterior region (LM 1, 2, 3, 14, 15, and 16). Their hyomandibular is shorter than that of the other species (LM 13), their maxillary process of the palatine is longer and more horizontal (LM 1and 2) and the quadrate-mandible articulation (LM 15) is clearly behind a vertical line going through the ethmo-palatine joint (LM 2 ). The opercle of the two species is less high but barely broader (LM 9, 10, 11, and 12). Between these extremes, the other species have an intermediate shape. On the other hand, S. nigricans and the two Plectroglyphidodon have a broad maxillary process of the palatine (LM 1 and 2) which is strongly ventrally bent. Their hyomandibular is broader in its lower part (LM 4, 5, and 13). Also note that $\mathrm{Pl}$. lacrymatus, $\mathrm{Pl}$. johnstonianus and Stegastes nigricans have the two hyomandibular articulation condyles on the neurocranium, which are more separated than in the other species (LM 6 and 7). The opercle is broader in its upper part in these three species (LM 10).

Concerning the mandible, RW1 and RW2 define $73.3 \%$ of the shape variation (Fig. 4) and allow the discrimination of four groups. The first consists only of Chromis acares, the second group is made up of C. margaritifer and Pomacentrus pavo and a third includes the two species of Plectroglyphidodon and Stegastes nigricans. Along the RW2 axis, the two Dascyllus species are isolated from $C$. margaritifer and $P$. pavo. The three species with the highest scores on RW1, Pl. lacrymatus, Pl. johnstonianus and S. nigricans, possess a higher mandible that appears more solid. The coronomeckelien is located very far forward and thus far away from the "quadrate-mandible" joint (LM 8 and 9). The dentary is strongly developed. The ventral region of the dentary, which constitutes the symphisis mandibulae, is longer (LM 1 and 12). The anterior part of the angular penetrates the dentary further than is the case in the other species (LM 9, 10, and 12). Opposite, C. acares shows the longest mandible. Its angular is long and thin (LM 3, 4, 5, 6, 7, 8, and 9). The dentary is spindly. The symphisis mandibulae is very short and the corono-meckelien (LM 8) is much closer to the "quadrate-mandible" articulation (LM 4) than in the other seven species. Pomacentrus pavo differs from C. margaritifer in having a slightly less 


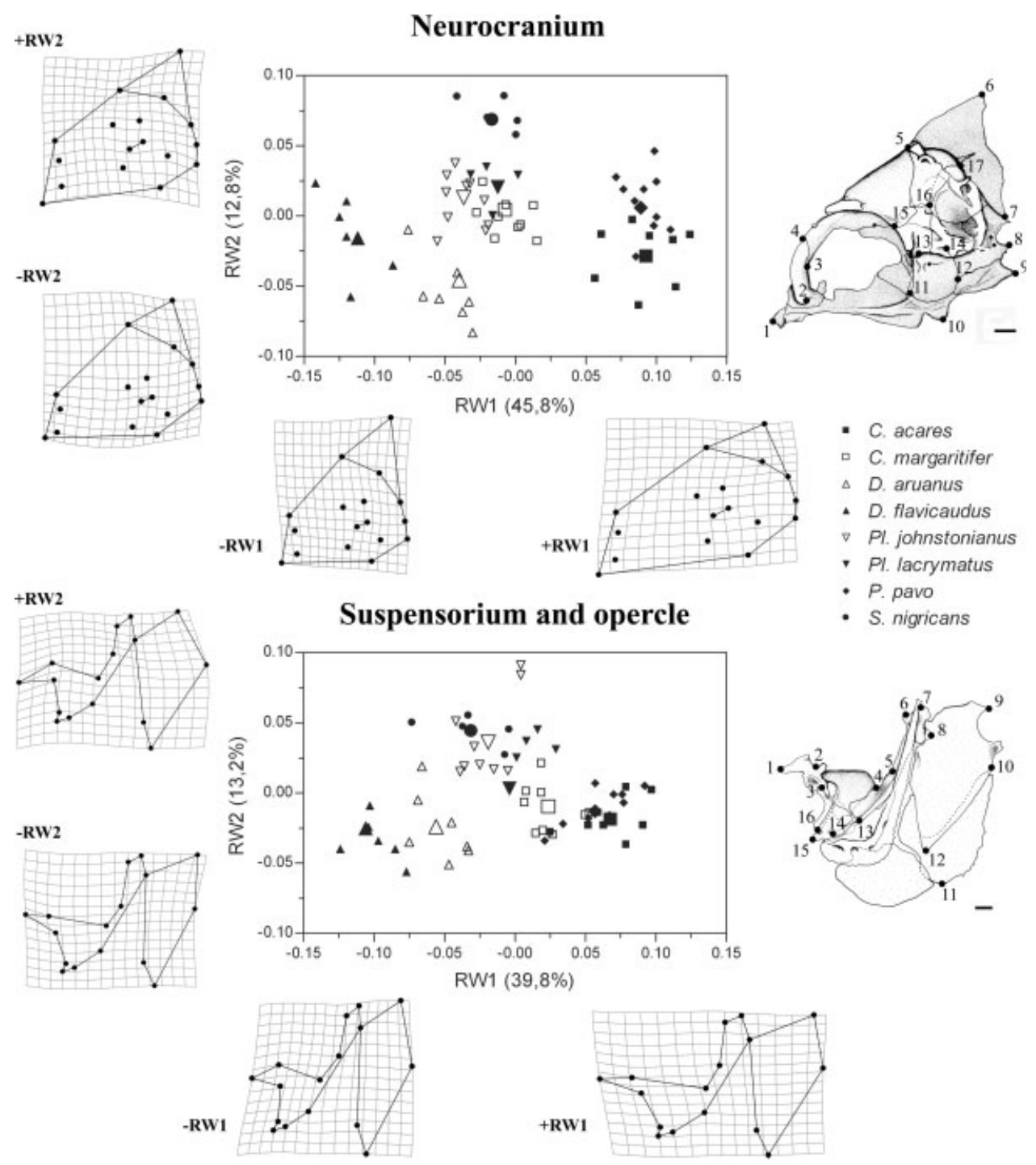

Fig. 3. Scatter plot of relative warp 1 and 2 (RW1 and RW2) of the neurocranium and the unit "suspensorium and opercle". Species means are shown by larger icons. TPS Deformation grids indicate shape variation represented by RW1 and RW2 (minimal (-RW) and maximal (+RW) values).

high mandible (LM 2 and 3). According to the RW2 axis, D. aruanus and D. flavicaudus are isolated from the other species. Their retroarticular is very much longer in its ventral part (LM 6 and 7).

On the level of the premaxilla (Fig. 4), the RW1 and the RW2 respectively account for about $62.9 \%$ and $16.1 \%$ of the total shape variation. In this shape space, the two species of Plectroglyphidodon and Stegastes nigricans are directly opposite to the other species on RW1. These three species possess the shortest dentigerous process (LM 1 and 6) and the longest ascending process (LM 1 and 2). Other opposite trends in shape variation are shown on RW2 by Chromis acares (+RW2) and the two Dascyllus (-RW2). The former species has a long and very thin ascendant process in its upper part (LM 2, 3, and 4) and a spindly dentigerous process while the two Dascyllus present a much broader dentigerous process (LM 1, 5, and 6).

For all bone structures, MANOVA revealed significant differences between species $(P<0.05$ for each skeletal structure) (Table 3), and pairwise comparisons based on Mahalanobis distances shows significant differences among species for each element $(P<0.05$ in every case). Discrimination among species can be also interpreted by examining the ordination of specimens in the shape space defined by the CV1 and CV2 axes (Fig. 5). For the neurocranium, these vectors together explain $78.7 \%$ of the total variation in the dataset while CV1 and CV2 account for $>84 \%$ of 


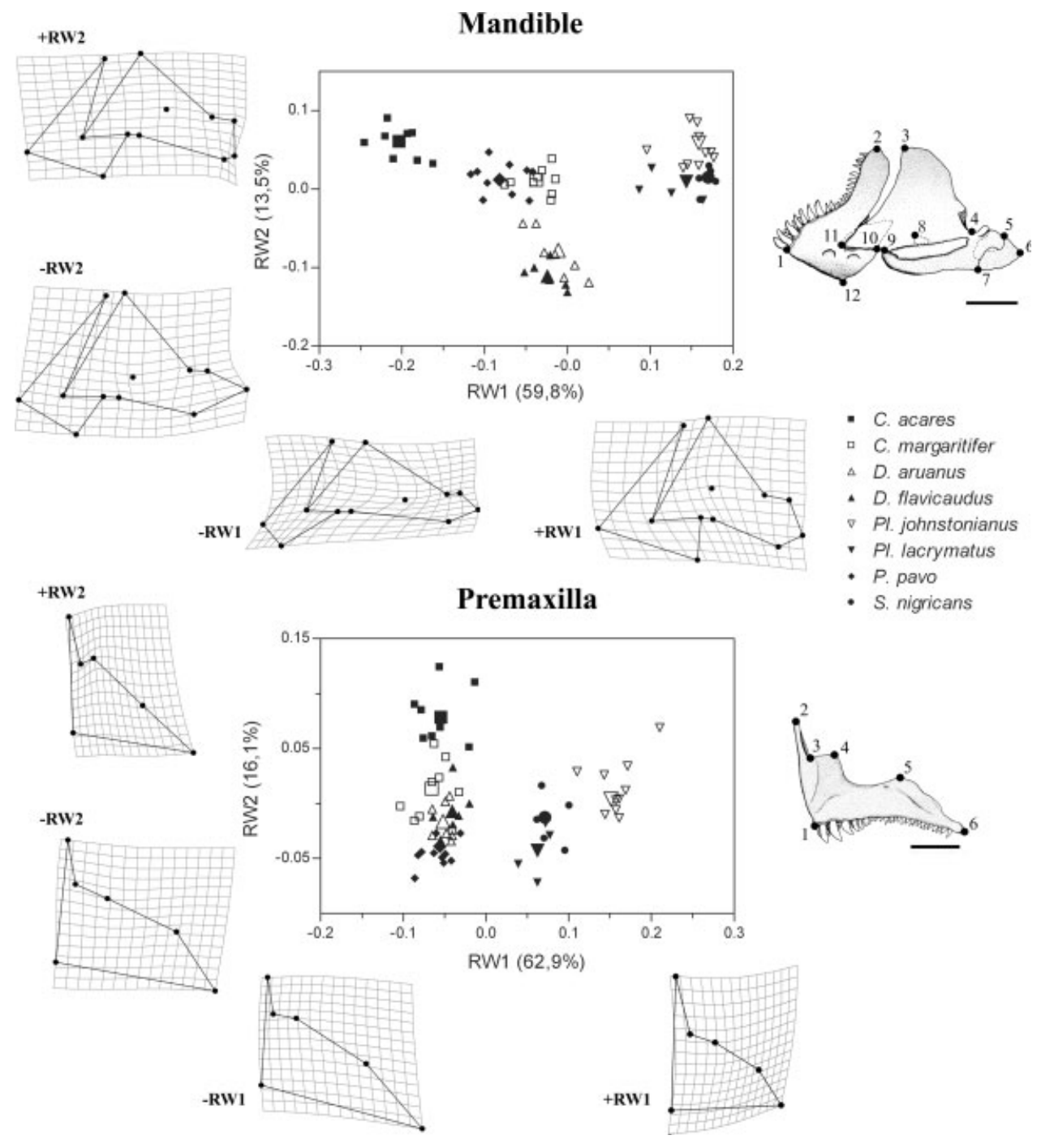

Fig. 4. Scatter plot of relative warp 1 and 2 (RW1 and RW2) of the mandible and the premaxilla. Species means are shown by larger icons. TPS Deformation grids indicate shape variation represented by RW1 and RW2 (minimal ( $-\mathrm{RW})$ and maximal (+RW) values).

the total shape variation in the other structures. Generally speaking, shape differences between species highlighted by CVA strengthen the previous description but they also allow presentation of some features not revealed by the RW analyses.

Concerning the neurocranium, all species are clearly separated in this shape space. Shape variations along CV1 confirm a proportionally longer neurocranium in Chromis acares and Pomacentrus pavo (+CV1, Fig. 6A). Plectroglyphidodon lacrymatus, $P l$. johnstonianus and Stegastes nigricans form an isolated cluster on CV2, sharing a short frontal region, a high supraoccipital crest, a high ethmoidal region and a vomer that is ventrally directed (+CV2, Fig. 6A). The other species have a broader supraoccipital crest and occipital region. Chromis margaritifer shows a neurocranium with an intermediate shape. For the "suspensorium and opercle" unit, the CV1 and CV2 axes clearly individualize each species except $P l$. lacrymatus, $P l$. johnstonianus and S. nigricans (Fig. 5). These last three species form a single group where the maxillary process of the palatine (LM 1 and 2) is broad and strongly ventrally bent (+CV1, Fig. 6B). To a lesser extent, the same character permits differentiation of $D$. aruanus, $D$. flavicaudus and $P$. pavo

TABLE 3. MANOVA for the shape variables (uniform and non-uniform shape components) of the four bone elements

\begin{tabular}{lrrrc}
\hline Element & $\lambda_{\text {WILKS }}$ & $F$ & df & $P$ \\
\hline $\begin{array}{l}\text { Neurocranium } \\
\text { Suspensorium }\end{array}$ & $1 \times 10^{-7}$ & 7.654 & 210,162 & $<0.0001$ \\
$\quad$ and opercle & $5 \times 10^{-7}$ & 6.717 & 196,175 & $<0.0001$ \\
Mandible & $3 \times 10^{-7}$ & 13.710 & 140,223 & $<0.0001$ \\
Premaxillary & $6.726 \times 10^{-4}$ & 12.468 & 56,242 & $<0.0001$ \\
\hline
\end{tabular}



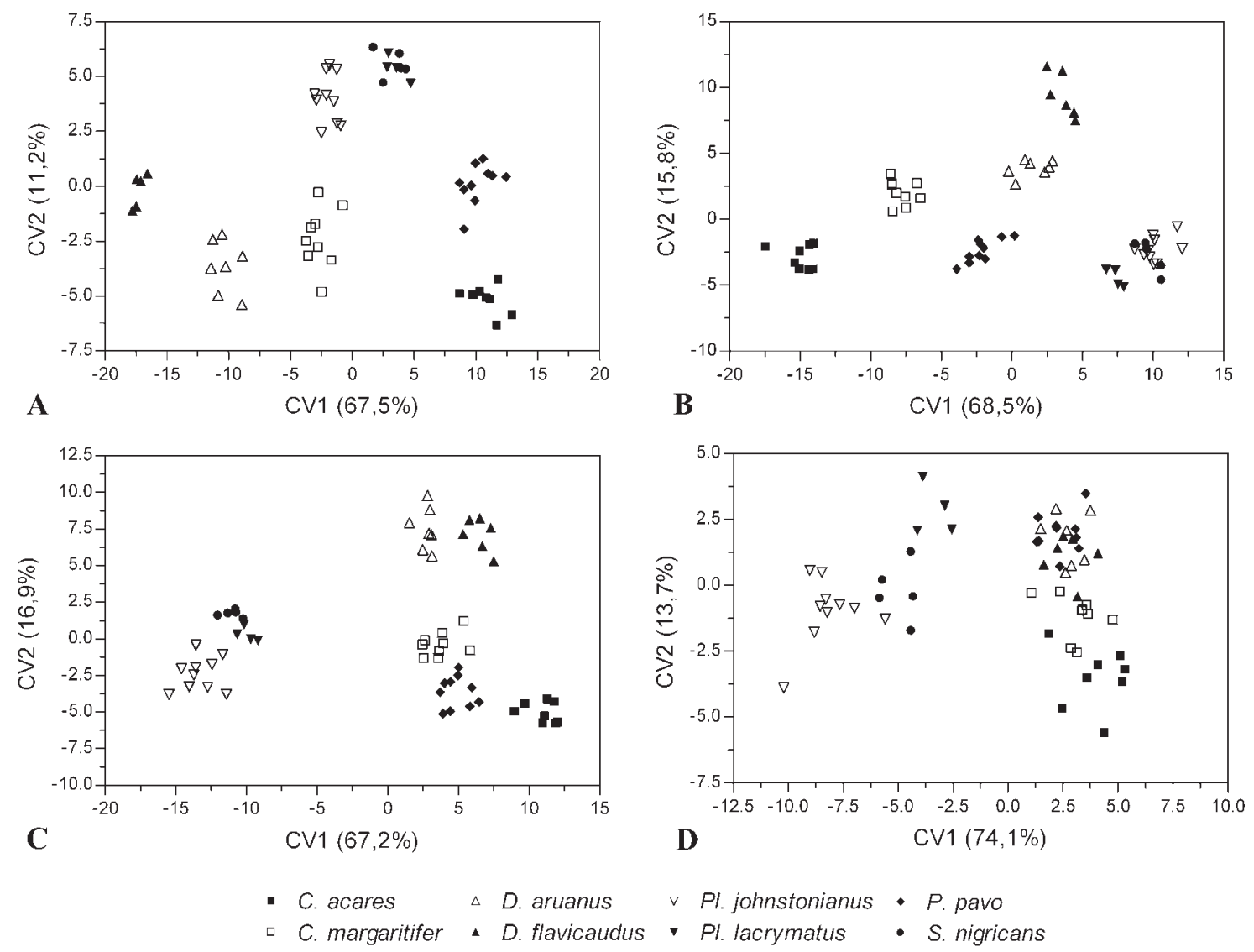

Fig. 5. Ordination of the eight species in the space of the first two canonical axes based on the matrix of shape variables (PWs); (A) the neurocranium; (B) the "suspensorium and opercle" unit; (C) the mandible; (D) the premaxilla.

from the two Chromis species. The two Dascyllus and C. margaritifer differ from the other species by a thinner hyomandibular and a shorter suspensorium and opercle along the antero-posterior axis (+CV2, Fig. 6B). Thus, this unit appears proportionally deeper in these three species. For the mandible (Fig. 5C) and the premaxilla (Fig. 5D), the first two canonical vectors allow the same discrimination of morphological groups than the RWs analysis and the shape features that separates the species is similar to those described along RW axes (Fig. 6C,D).

In a test for interspecific allometry, the linear regressions of PWs scores onto CS were significant for all structures (Table 4). Percentage of unexplained variance in these models $(>82 \%$, Table 4$)$ shows no strong relation between size and shape in the studied species.

The phenograms based on the matrix of Procrustes distances among the mean shape of each species allow the determination of the degree of morphological similarity between species (Fig. 7). The results reinforce the ordinations obtained in the shape space defined by CV1 and CV2 for each skeletal unit. Concerning the neurocranium, Chro- mis acares and Pomacentrus pavo form a first cluster (Fig. 7). Curiously, these species share a similar neurocranium shape whereas they have very different diets; $C$. acares is a zooplankton feeder and $P$. pavo is omnivorous, feeding mainly on algae. The second group of species is divided by the successive divergences of the two omnivorous Dascyllus species. Finally, a last cluster formed of the coral polyp feeder Plectroglyphidodon johnstonianus and both herbivorous, Pl. lacrymatus and Stegastes nigricans, is separated from $C$. margaritifer which eats zooplankton. On the basis of similarity of form of the "suspensorium and opercle" unit (Fig. 7), $D$. aruanus and $D$. flavicaudus determine a first cluster. Chromis acares and P. pavo form a second separated from the last four species. The clusterings obtained for the mandible and the premaxilla are identical (Fig. 7). The two main clusters separate both the coral polyp feeder $P l$. johnstonianus and the herbivorous $P l$. lacrymatus and S. nigricans from the other five species. This last group of species is subdivided into three clusters. The first consists of only $C$. acares and the last two are, respectively, made up of both species of Dascyllus, and of the species P. pavo and C. margaritifer. 
$-\mathrm{CV} 1$
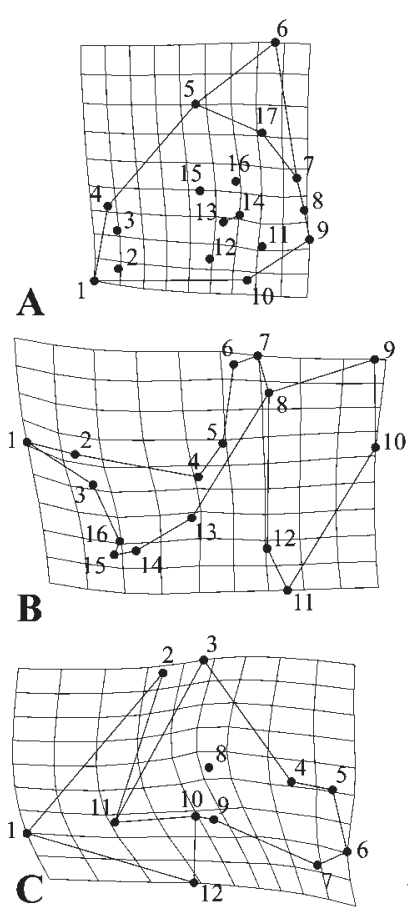

D

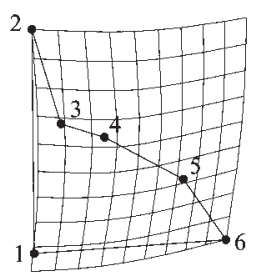

$+\mathrm{CV} 1$
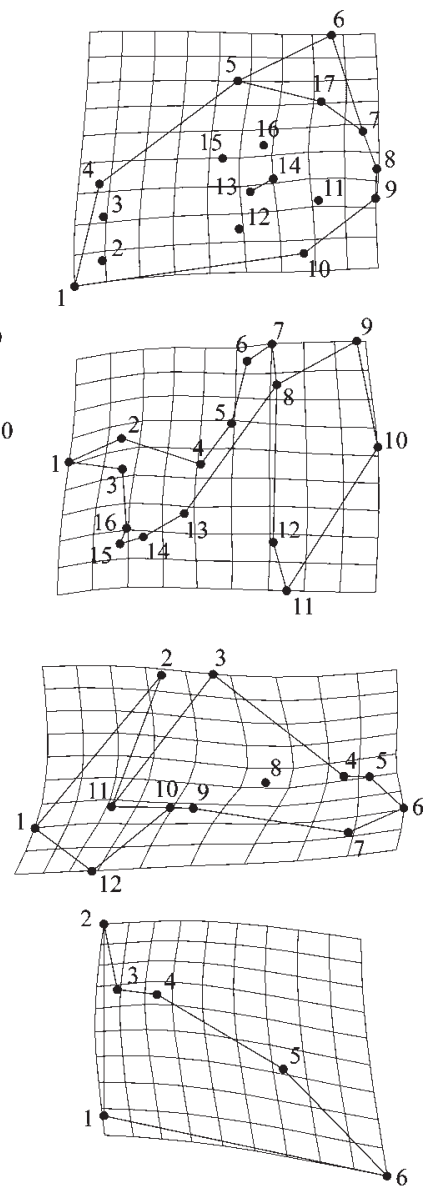

$-\mathrm{CV} 2$
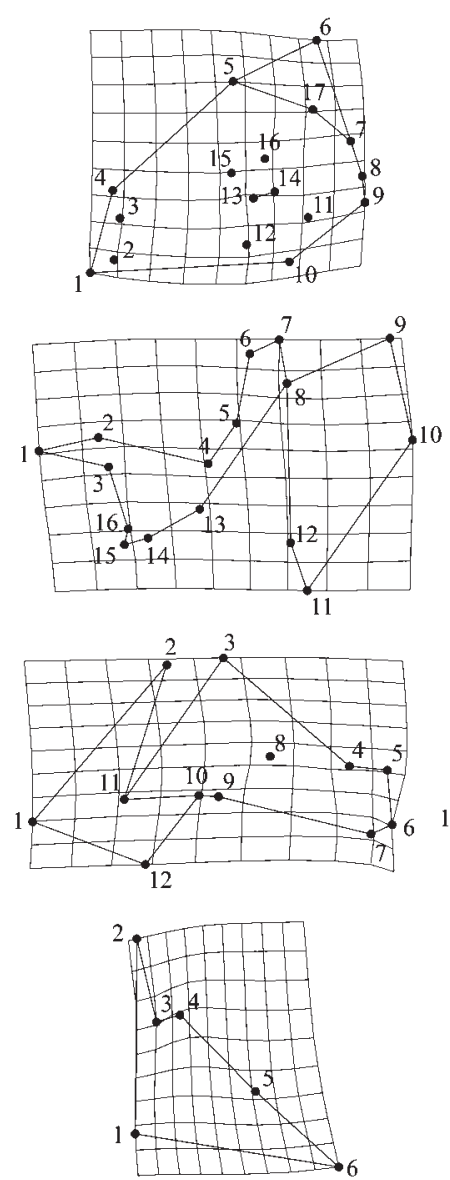

$+\mathrm{CV} 2$
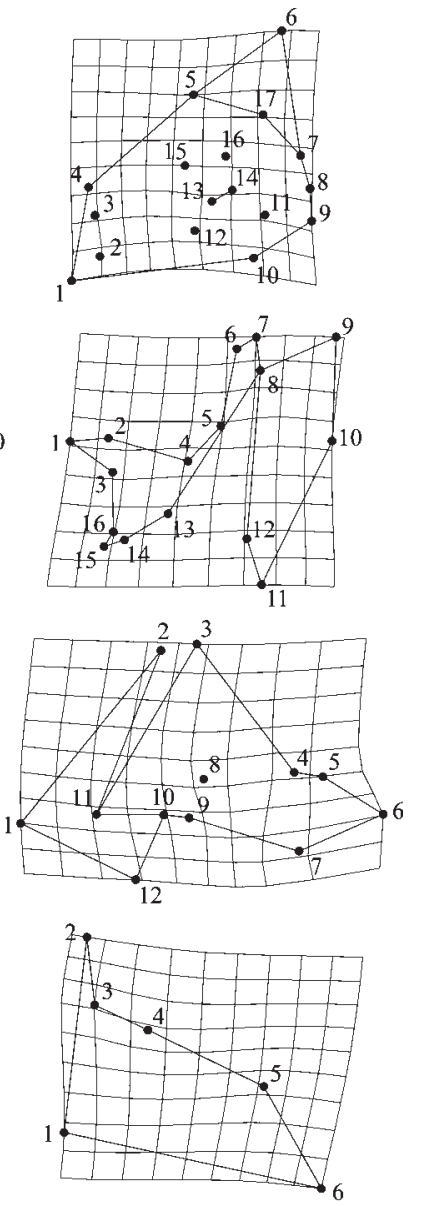

Fig. 6. TPS Deformation grids depicting (A) neurocranium; (B) suspensorium and opercle; (C) mandible and (D) premaxilla shape variations at positive and negative deviations along the first (CV1) and second (CV2) canonical variates axes.

\section{DISCUSSION}

The study of prey-capture apparatus morphology allows us to predict, with reasonable probability, how the organism feeds but not exactly what it feeds on (Barel, 1983; Motta, 1988; Liem, 1993). The differences between the morphological structures are normally translated by variations in the performance of the organisms achieving a definite task (Wainwright and Richard, 1995).

The bucco-pharyngeal cavity of a fish has been modelled as a truncate cone, whose small base is the circular opening of the mouth and whose large base is located behind the branchial basket on the level of the opercles (Alexander, 1967; Lauder, 1980; Lauder and Lanyon, 1980; Vandewalle and Chardon, 1981; Liem, 1993). The efficiency of the cone depends on various factors such the morphology of the skull and particularly of the buccopharyngeal cavity (Liem, 1990).

There are three broad methods of prey capture according to the degree of truncation of the cone
(Liem, 1980, 1993): suction feeding, ram feeding and manipulation. However, a mode of prey capture is not exclusive; many teleosts are able to modulate their feeding mode and to move from one category to another (Liem, 1980, 1993; Wainwright and Richard, 1995; Ferry-Graham et al., 2002). If Pomacentridae skull morphology allows us to consider they are suction feeders (Emery, 1973; Gluckmann and Vandewalle, 1998; Frédérich et al., 2006; present study), geometric morphometric

TABLE 4. Multivariate tests of significance for linear regressions of shape variables (uniform and non-uniform shape components) onto CS of the four bone elements

\begin{tabular}{lcccc}
\hline Element & & & & $\begin{array}{c}\text { Percent } \\
\text { unexplained }\end{array}$ \\
\hline Neurocranium & 0.103 & 8.148 & $1.4 \times 10^{-7}$ & 82.4 \\
Suspensorium & 0.196 & 4.386 & $6.7 \times 10^{-5}$ & 87.7 \\
$\quad$ and opercle & & & & \\
Mandible & 0.196 & 7.812 & $3.8 \times 10^{-8}$ & 82.1 \\
Premaxillary & 0.590 & 4.344 & $5 \times 10^{-4}$ & 93.3 \\
\hline
\end{tabular}



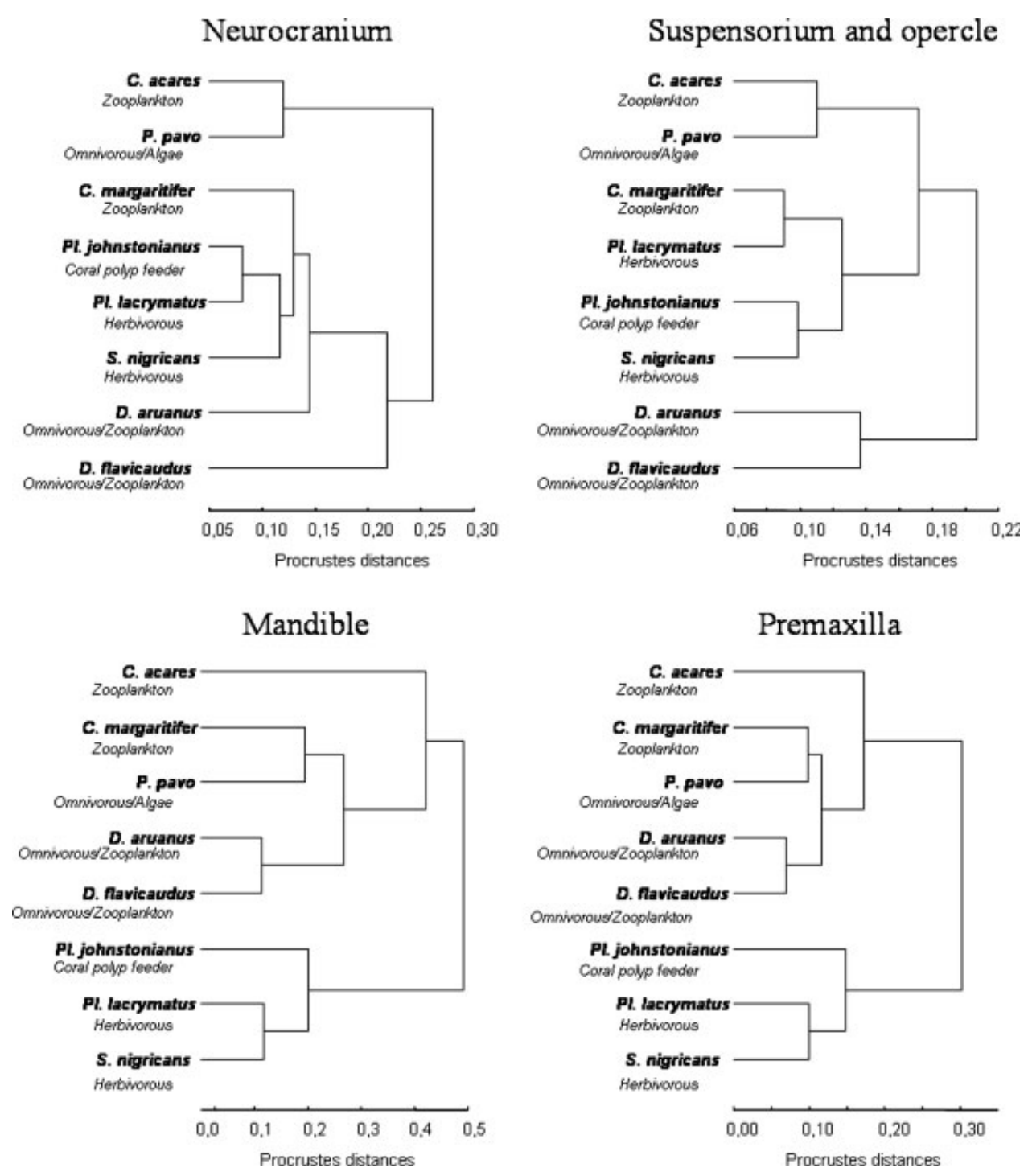

Fig. 7. Phenogram based on Procrustes shape distances in the analysis of the species means for the neurocranium; the "suspensorium and opercle" unit; the mandible and the premaxilla. Diets are reported for each species (see Table 1).

techniques permit deeper understanding of the different ways of feeding and highlighting different adaptations among species.

\section{Zooplankton Feeders and Omnivores (Suction Feeders and Ram-Feeders)}

Chromis acares, C. margaritifer, Dascyllus aruanus and $D$. flavicaudus are considered as zooplankton feeders. Their diet implies the capacity to suck small prey in the water column (Barel, 1983; Liem, 1993). These fishes often have a skull shaped to improve the design of the cone such as high suspensoria and opercles (Fig. 3) increasing the diameter of the base of the cone (Liem and Osse, 1975; Liem, 1979; Lauder, 1980). This character is the most important in the two Dascyllus species and, to a lesser extent, in C. margaritifer making these species true suckers. The two Dascyllus species also have a high supraoccipital crest (Figs. 3, 6) for the insertion of a well-developed epaxial muscle mass responsible for the rise of the neurocranium during mouth opening (Liem, 1993). Suckers usually have a long ascending process (Gosline, 1981), but this is not the case in these three species. However, their premaxillaries are thin (Figs. 4, 6) matching that these species do not need strong jaws to suck zooplankton. Moreover, these three species have caniniform teeth arranged in several lines on the oral jaws (personal observations), which are typical of species catching their food by suction (Emery, 1973; Barel, 1983).

Compared to the other species of this trophic guild, Chromis acares shows a distinct shape of 
mandible, suspsensorium and opercle, and neurocranium. Its mandibles are the longest and thinnest, its coronoid processes are proportionally the shortest, the cranium is lengthened, the suspensorium is long with a maxillary process of the palatine that is directed dorsally, and the opercle is less high. This results in a less efficient suction cone in $C$. acares than in the other zooplanktivores. According to all these characters, C. acares should be considered as a ram feeder. In these fish, the gape of the mouth is only slightly smaller in diameter than the base of the cone (Liem, 1993), causing a small pressure drop in the buccal cavity. The fish chases after its prey, swimming with an open mouth and open gills. The protrusion, enhanced by a long ascending process of the premaxilla (Gosline, 1981), is only used to decrease the predator-prey distance (Barel, 1983; Coughlin and Strickler, 1990).

\section{Herbivores and Corallivores (Grazers)}

The grazers include Plectroglyphidodon johnstonianus, Pl. lacrymatus, Pomacentrus pavo and Stegastes nigricans. These four fish species mainly eat algae removed from the substrate or coral polyps (Table 1). In both cases, prey capture implies that the biting ability is followed by the suction capacity. Consequently, these fishes also show a cone-shaped buccal cavity, as in the case of suction-feeders. The differences between both groups are primarily at the level of the robustness of certain skeletal parts, mainly of the suspensorium and jaws. The mandibles are characterized by higher coronoid processes than in zooplanktivores (Figs. 4, 6). This development increases the insertion sites of the adductor mandibulae muscle complex (Barel, 1983; Albertson and Kocher, 2001; Kassam et al., 2004). A longer dentary symphysis between the left and the right mandibles solidifies the lower jaw. In parallel, the hyomandibular shows a broader insertion site for the adductor mandibulae muscle, while its articulation condyles are more separated (Figs. 3, 6), indicating they could better prevent deformation due to the action of the adductor mandibulae muscle (ElshoudOldenhave and Osse, 1976; Vandewalle, 1978; Gluckmann and Vandewalle, 1998; Parmentier et al., 1998). The maxillary process of the palatine in $\mathrm{Pl}$. lacrymatus, $\mathrm{Pl}$. johnstonianus and $\mathrm{S}$. nigricans is broad and ventrally bent (Fig. 4), which makes the maxillary and the palatine more interdependent. Their vomer is also ventrally directed (Fig. 6A). They provide points of support during grazing, increasing the cutting force (Barel, 1983; Turingan, 1994; Parmentier et al., 2000).

A link may be established between oral jaw morphology and feeding habit through lever arm mechanics of the lower jaw (Turingan, 1994; Wainwright and Richard, 1995). Crushing and biting species have higher jaw closing lever ratios than do suction-feeding species. In Pomacentridae, the bundle $A 3 \beta$ of the adductor mandibulae is the wider muscle inserting into the articulo-angular and this could play a major role during jaw closing. The insertion of the adductor mandibulae is on the medial face of the lower jaw, on the coronomeckelien (Gluckmann et al., 1999). In the two species of Plectroglyphidodon and Stegastes nigricans, the coronomeckelien is very far forward of the "quadrate-mandible" joint (Figs. 4, 6). Consequently, these three species have better mechanical properties for biting with a high jaw closing lever ratio. This also suggests a good capacity for forceful seizure.

Pomacentrus pavo occupies an intermediate position. Indeed, this species also presents incisiform teeth bringing it closer to grazers (personal observations), and exhibits similar morphological characteristics to a planktivore such as Chromis acares (centroid size of the neurocranium and the unit "suspensorium and opercle", long ascending arm of the premaxilla, long and shallow suspensorium, lengthened neurocranium, broad opercle). These characteristics would corroborate its omnivorous diet (Table 1).

\section{Interspecific Comparisons of Size}

No strong relation exists between the size (CS) and the shapes in the eight studied species (Table 4). Size is a variable permitting the explanation of diversity in damselfishes. Dascyllus aruanus and D. flavicaudus have very similar shapes but they strongly differ in their sizes (SL and CSs). This could be related to differences in diet (type or size of the selected plankton) or in habitat use; $D$. aruanus lives in association with branched corals and D. flavicaudus forages in the water column just above the reef. Difference in size between the two Chromis species and the two herbivorous, Plectroglyphidodon lacrymatus and Stegastes nigricans, could also help to explain some resource partitioning (diet and habitat). Plectroglyphidodon lacrymatus is a solitary species living in shelters. On the other hand, S. nigricans is a farming species that defends its territory from other herbivorous fish like surgeonfishes (Acanthuridae) and other damselfishes (Robertson, 1996). Competitive abilities of $S$. nigricans in guarding its area are probably optimized by its large size.

\section{Evolution and Phylogenetic Aspects in Pomacentridae}

The aim of ecomorphological studies is to reveal and understand possible relationships between an organism's morphology and its way of life (Norton et al., 1995). The morphology of a species consequently appears as an assembly of functional char- 


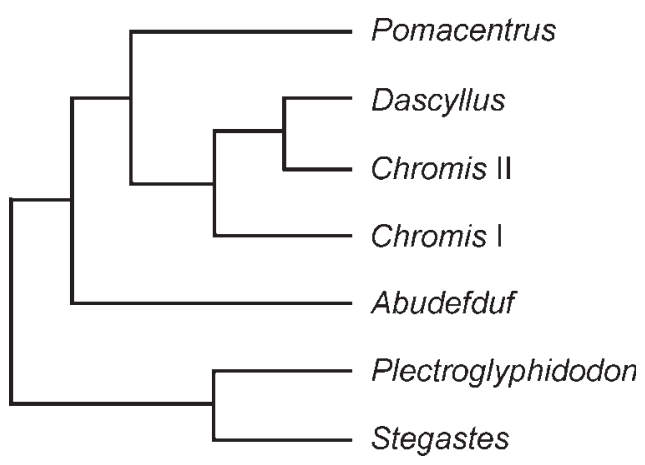

Fig. 8. Phylogenetic relationships among the five studied Pomacentridae genera according to Tang (2001), Jang-Liaw et al. (2002), and Quenouille et al. (2004). The genus Abudefduf forms an intermediate group not studied in the present study.

acters interacting with environmental factors. However, some authors have referred to the difficulties of making ecomorphological studies without taking into account the phylogenetic relations between species (e.g., Clifton and Motta, 1998), because these relationships can also influence the morphology and the ecology of species (Westneat, 1995). In other words, the phyletic relationship will dictate some of the morphological and ecological similarities between species (Motta, 1988; Douglas and Matthews, 1992).

Phenetic relationships of the mandible and the premaxilla are very similar with their phylogeny (Tang, 2001; Jang-Liaw et al., 2002; Quenouille et al., 2004) (Fig. 8). The division of the eight species into two functional groups as (1) the suckers and ram feeders (zooplankton feeders and omnivores), and (2) the "grazers" (herbivores and corallivores) corresponds to the first node of the phylogenetic tree of Quenouille et al. (2004). This node isolates a mainly herbivorous group (Ciardelli, 1967; Allen, 1991) including Plectroglyphidodon, Stegastes, Microspathodon, Parma and Hypsipops [Clade 4, according to Quenouille et al. (2004)]. However, $\mathrm{Pl}$. johnstonianus is specialized in coral grazing (Kuo and Shao, 1991). The other genera include all zooplanktivorous and omnivorous species (Allen, 1991; Kuo and Shao, 1991).

According to molecular phylogenetic studies (Tang, 2001; Jang-Liaw et al., 2002; Quenouille et al., 2004), the genus Chromis is polyphyletic and is divided into two clusters: Chromis I and Chromis II, the latter being the sister taxa of Dascyllus (Fig. 8). Our morphological study reinforces this hypothesis. The morphology of $C$. acares is comparable to that of the ram feeder Chromis viridis (Coughlin and Strickler, 1990; Frédérich et al., 2006), which belongs to Chromis I. On the other hand, our study shows that the morphology of $C$. margaritifer is closer to that of the Dascyllus species, confirming its position in Chromis II (Quenouille et al., 2004). All Chromis are regarded as zooplanktivorous and the Dascyllus as omnivorous, feeding largely on zooplankton (Allen, 1991). Consequently, the division made between the group Chromis I (ram feeders) and the group "Dascyllus + Chromis II" (suckers) could correspond to a change in the strategy of prey capture in the water column during evolution.

The grazers Plectroglyphidodon and Stegastes are placed at the base of the phylogenetic tree of pomacentrids, supporting the herbivorous character of the ancestral species. Pomacentrus pavo also feeds on algae but is closer to Chromis and Dascyllus, than to Plectroglyphidodon and Stegastes (Fig. 8). Our quantitative shape analyses corroborate this result (Fig. 7). It should be admitted that grazers appeared twice during the evolution of Pomacentridae. This hypothesis is reinforced by the morphology of $P$. pavo that shares similar skeletal shapes with zooplanktivores. These similarities show that the (secondary) herbivorous character in $P$. pavo appears to be derived from the sucker and/or ram-feeder shape(s). It also explains that its cutting abilities differ from those of the three primary grazers.

In this study, significant differences in shapes and size of four skeletal units in the trophic apparatus were revealed, both within and between trophic guilds. Moreover, our results suggest that trophic morphology, playing roles in resource use and partitioning, would be able to explain a part of the diversity of Pomacentridae.

\section{ACKNOWLEDGMENTS}

We are grateful to A. Cardini (University of York, UK) for his suggestions and advices on geometric morphometric analyses, to M. Chardon and two anonymous referees for their constructive and helpful comments on the manuscript. The authors thank P. Smith for her linguistic assistance.

\section{LITERATURE CITED}

Albertson RC, Kocher TD. 2001. Assessing morphological differences in an adaptive trait: a landmark-based morphometric approach. J Exp Zool 289:385-403.

Alexander RMcN. 1967. The functions and mechanisms of the protrusible upper jaws of some acanthopterygian fish. J Zool 151:43-64.

Allen GR. 1991. Damselfishes of the World. Mergus, Melle: Publication of natural history and pets book. $272 \mathrm{p}$.

Barel CDN. 1983. Towards a constructional morphology of cichlid fishes (Teleostei, Perciformes). Neth J Zool 33:357424.

Bookstein FL. 1991. Morphometric Tools for Landmark DataGeometry and Biology. Cambridge: Cambridge University Press. 435 p.

Cardini A. 2003. The geometry of the marmot (Rodentia: Sciuridae) mandible: Phylogeny and patterns of morphological evolution. Syst Biol 52:186-205.

Ciardelli A. 1967. The anatomy of the feeding mechanism and the food habits of Microspathodon chrysurus (Pisces: Pomacentridae). Bull Mar Sci 17:843-883. 
Clements KD, Choat JH. 1993. Influence of season, ontogeny and tide on the diet of the temperate marine herbivorous fish Odax pullus (Odacidae). Mar Biol 117:213-220.

Clifton KB, Motta PJ. 1998. Feeding morphology, diet, and ecomorphological relationships among five caribbean labrids (Teleostei, Labridae). Copeia 4:953-966.

Coughlin DJ, Strickler JR. 1990. Zooplankton capture by a coral reef fish: An adaptative response to evasive prey. Environ Biol Fishes 29:35-42.

Douglas ME, Matthews WJ. 1992. Does morphology predict ecology? Hypothesis testing within a fresh-water stream fish assemblage. Oikos 65:213-224.

Elshoud-Oldenhave MW, Osse JW. 1976. Functional morphology of the feeding system in the Ruff - Gymnocephalus cernua (L. 1758) - (Teleostei, Percidae). J Morphol 150:399-422.

Emery AR. 1973. Comparative ecology and functional osteology of fourteen species of damselfish (Pisces: Pomacentridae) at Alligator reef, Florida Keys. Bull Mar Sci 23:649-770.

Ferry-Graham LA, Wainwright PC, Westneat MW, Bellwood DR. 2002. Mechanisms of benthic prey capture in wrasses (Labridae). Mar Biol 141:819-830.

Frédérich B, Parmentier E, Vandewalle P. 2006. A preliminary study of development of the buccal apparatus in Pomacentridae (Teleostei, Perciformes). Anim Biol 56:351-372.

Gluckmann I, Vandewalle P. 1998. Morphofunctional analysis of the feeding apparatus in four Pomacentridae species: Dascyllus aruanus, Chromis retrofasciata, Chrysiptera biocellata and C. unimaculata. Ital J Zool 65:421-424.

Gluckmann I, Bussers J-C, Poulicek M, Vandewalle P. 1999. Preliminary study of the morphology of the head in Pomacentridae: Adductor mandibulae organization in Dascyllus aruanus (Teleostei: Perciformes). In: Séret B, Sire J-Y, editors. Proceedings of the 5th Indo-Pacific Fish Conference, Nouméa: Société Française d'Ichtyologie \& Institut de Recherche pour le Développement. pp 89-97.

Gosline WA. 1981. The evolution of the premaxillary protrusion system in some teleostan fish groups. J Zool 193:11-23.

Jang-Liaw N-H, Tang KL, Hui C-F, Shao K-T. 2002. Molecular phylogeny of 48 species of damselfishes (Perciformes: Pomacentridae) using $12 \mathrm{~S}$ mtDNA sequences. Mol Phylogenet Evol 25:445-454.

Kassam D, Adams DC, Yamaoka K. 2004. Functional significance of variation in trophic morphology within feeding microhabitat-differentiated cichlid species in Lake Malawi. Anim Biol 54:77-90.

Kotrschal K. 1989. Trophic ecomorphology in eastern pacific blennioid fishes: Character transformation of oral jaws and associated change of their biological roles. Environ Biol Fishes 24:199-218.

Kuo SR, Shao KT. 1991. Feeding habits of damselfish (Pomacentridae) from the southern part of Taiwan. J Fish Soc Taiwan 18:165-176.

Lauder GV. 1980. The suction feeding mechanism in sunfishes (Lepomis): An experimental analysis. J Exp Biol 88:49-72.

Liem KF, Osse JW. 1975. Biological versatility, evolution, and food resource exploitation in African Cichlid fishes. Am Zool 15:427-454.

Liem KF. 1979. Modulatory multiplicity in the feeding mechanism in cichlid fishes, as exemplified by the invertebrate pickers of Lake Tanganika. J Zool 189:93-125.

Liem KF. 1980. Adaptive significance of intra- and interspecific differences in the feeding repertoires of cichlid fishes. American Zoologist 20:295-314.

Liem KF. 1990. Aquatic versus terrestrial feeding modes: possible impacts on the trophic ecology of vertebrates. Am Zool 30:209-221.

Liem KF. 1993. Ecomorphology of the Teleostean skull. In: Hanken J, Hall BK, editors. The Skull, Vol. 3: Functional and Evolutionary Mechanisms. Chicago: The University of Chicago press. pp 423-452.

Lauder GV, Lanyon LE. 1980. Functional anatomy of feeding in the Bluegill sunfish Lepomis macrochirus: In vivo measurement of bone strain. J Exp Biol 84:33-55.
Marcus LF, Corti M, Loy A, Naylor G, Slice D. 1996. Advances in Morphometrics. New York: Plenum Press.

McCormick MI. 1998. Ontogeny of diet shifts by a microcarnivorous fish, Cheilodactylus spectabilis: Relationship between feeding mechanics, microhabitat selection and growth. Mar Biol 132:9-20.

Meekan MG, Steven ADL, Fortin MJ. 1995. Spatial patterns in the distribution of damselfishes on a fringing coral reef. Coral Reefs 14:151-161.

Monteiro LR. 1999. Multivariate regression models and geometric morphometrics: The search for causal factors in the analysis of shape. Syst Biol 48:192-199.

Monteiro NM, Quinteira SM, Silva K, Vieira MN, Almada VC. 2005. Diet preference reflects the ontogenetic shift in microhabitat use in Lipophrys pholis. J Fish Biol 67:102-113.

Motta PJ. 1988. Functional morphology of the feeding apparatus of ten species of Pacific butterflyfishes (Perciformes, Chaetodontidae): An ecomorphological approach. Environ Biol Fishes 22:39-67.

Nelson JS. 2006. Fishes of the World. Hoboken: Wiley. 601 p.

Norton SF, Luczkovich JJ, Motta PJ. 1995. The role of ecomorphological studies in the comparative biology of fishes. Environ Biol Fishes 44:287-304.

Ormond RFG, Roberts JM, Jan R-Q. 1996. Behavioural differences in microhabitat use by damselfishes (Pomacentridae): Implications for reef fish biodiversity. J Exp Mar Biol Ecol 202:85-95.

Parmentier E, Chardon M, Poulicek M, Bussers J-C, Vandewalle, P. 1998. Morphology of the buccal apparatus and related structures in four Carapidae. Aust J Zool 46:391-404.

Parmentier E, Castro-Aguirre JL, Vandewalle P. 2000. Morphological comparison of the buccal apparatus in two bivalve commensal Teleostei: Encheliophis dubius and Onuxodon fowleri (Carapidae, Ophidiiformes). Zoomorphology 120:2937.

Quenouille B, Bermingham E, Planes S. 2004. Molecular systematics of the damselfishes (Teleostei: Pomacentridae): Bayesian phylogenetic analyses of mitochondrial and nuclear DNA sequences. Mol Phylogenet Evol 31:66-88.

Robertson DR. 1996. Interspecific competition controls abundance and habitat use of territorial caribbean damselfishes. Ecology 77:885-899.

Rohlf FJ. 1993. Relative warps analysis and an example of its application to mosquito wings. In: Marcus LF, Bello E, Garcia-Valdecasas A, editors. Contributions to Morphometrics, Madrid: Monografias del Museo Nacional de Ciencias Naturales, CSIC. pp 131-159.

Rohlf FJ. 1996. Morphometric spaces, shape components and the effects of linear transformations. In: Marcus LF, Corti M, Loy A, Naylor GJP, Slice D, editors. Advances in Morphometrics. New York: Plenum Press. pp 117-129.

Rohlf FJ. 1999. On the use of shape spaces to compare morphometric methods. Hystrix 11:1-17.

Rohlf FJ, Slice D. 1990. Extensions of the procrustes method for the optimal superimposition of landmarks. Syst Zool 39:4059 .

Rohlf FJ, Marcus LF. 1993. A revolution in morphometrics. Trends Ecol Evol 8:129-132.

Sanderson SL. 1990. Versatility and specialization in labrid fishes: Ecomorphological implications. Oecologia 84:272-279.

Tang KL. 2001. Phylogenetic relationships among damselfishes (Teleostei: Pomacentridae) as determined by mitochondrial DNA data. Copeia 3:591-601.

Taylor WR, Van Dyke GC. 1985. Revised procedure for staining and clearing small fishes and other vertebrates for bone and cartilage study. Cybium 9:107-121.

Thompson DA. 1917. On Growth and Form. Cambridge: Cambridge University Press.

Turingan RG. 1994. Ecomorphological relationships among Caribbean tetraodontiform fishes. J Zool Lond 223:493-521.

Vandewalle P. 1978. Analyse des mouvements potentiels de la région céphalique du goujoun, Gobio gobio (L.) (Poisson, Cyprinidae). Cybium 3:15-33. 
Vandewalle P, Chardon M. 1981. Réflexions sur les rapports entre forme, structure et fonction chez des poissons de la famille des Cyprinidae. Cybium 5:67-70.

Wainwright PC. 1988. Morphology and ecology: Functional basis of feeding constraints in caribbean labrid fishes. Ecology 69:635-645.

Wainwright PC. 1996. Ecological explanation through functional morphology: The feeding biology of sunfishes. Ecology 77:1336-1343.

Wainwright PC, Bellwood DR. 2002. Ecomorphology of feeding in coral reef fishes. In: Sale PF, editor. Coral Reef Fishes: Dy- namics and Diversity in a Complex Ecosystem. San Diego: Academic Press. pp 33-57.

Wainwright PC, Richard BA. 1995. Predicting patterns of prey use from morphology of fishes. Environ Biol Fishes 44:97113.

Wainwright PC, Bellwood DR, Westneat MW, Grubich JR, Hoey AS. 2004. A functional morphospace for the skull of labrid fishes: patterns of diversity in a complex biomechanical system. Biol J Linnean Soc 82:1-25.

Westneat MW. 1995. Phylogenetic systematics and biomechanics in ecomorphology. Environ Biol Fishes 44:263-283. 